\title{
China passes copyright law
}

\section{Hong Kong}

CHINA, long regarded as a black hole for protection of intellectual property rights and copyrights, has begun to implement its first copyright law. This could prove to be the initial step in opening China up to a variety of imports, particularly computer software, but critics say the country still has a long way to go before innovators can trust that their work will not be used without credit or compensation there.

The new copyright law went into effect at the beginning of June, and a supplementary law that deals with software regulations will take effect 1 October. The legislation does not specifically deal with patents, which are covered by an existing statute that Western countries have complained is relatively lax.

Still, the copyright law should cause a major improvement in opportunities for doing business in China. According to the State Copyright Bureau, which has the responsibility for implementation, the law will - at least to some extent - help reduce the violations of copyrights, patents and intellectual property that have made Western companies wary of operating in China.

Passage of the law follows several years of complaints by European and US companies that their copyrights and patents gave them essentially no protection against unauthorized copying in China. Industry sources estimate that pirating of copyrighted goods in China costs the United States alone about $\$ 430$ million each year. The Business Software Alliance, a Washington-based group that lobbies for stronger protection of intellectual property

\section{British Science}

WE shall be publishing on 12 September Nature's Manifesto for British Science, which will be offered without charge to any one of the political parties contesting the next general election, and in the belief that it is an improvement on their own version.

Following publication, on Friday 13 September, there will be a public meeting at the Royal Institution, Albemarle Street, London W1 at which Sir Mark Richmond, chairman of the Science \& Engineering Research Council, will be the principal speaker. The chairman will be John Maddox, Editor of Nature. The meeting will start at 9.45 a.m. and end at 12.45 p.m. The political parties will be invited to send representatives, but there will be ample time for discussion. Those wishing to attend should apply for tickets to Mary Sheehan, Nature, 4 Little Essex Street, London WC2R 3LF. rights worldwide, refuses even to estimate the total of indirect losses that the software industry has suffered because of the lack of protection. In the absence of a copyright law, it claims, companies have decided not to sell in China, thereby missing out on huge but uncountable profits.

The Chinese government has gone some distance to meet foreign complaints in the language of the new law. For example, it permits companies to own the copyrights of published works created by their employees. An early version of the legislation would have given the copyrights to the employees, and would have permitted their companies to use the work without permission for only two years. In addition, the law limits the use of copyrighted works, such as software, by education institutions. Initially, educational establishments would have had virtually unlimited use of copyrighted material, setting up the possibility that China could copy and distribute specific pieces of software throughout its vast educational system without paying royalties.

No one expects the new copyright law to be a panacea, however. For example, the State Copyright Bureau has recently embarked on the task of publicizing the legislation and educating people on intellectual property and related matters and has found it a tough challenge, according to Shen Rengan, Copyright Department Director of the Bureau. "It takes time for people on the mainland to get familiar with the law, as they have long been weak in the legal sense of identifying intellectual property and physical property, thus posing difficulties to the Bureau when putting the law into effect," Shen told a recent seminar in Hong Kong.

Groups such as the Business Software Alliance complain that the legislation is too weak. One major objection is that neither the law nor the regulations protect works of foreign authors published abroad in the absence of a bilateral or multilateral treaty to which China and the author's country are parties. At present, China is party to no such treaties. However, Shen said China is negotiating with the government of Hong Kong and local authors' associations on possible pacts.

The software alliance also complains that computer programs are not protected as literary works, and that neither the law nor the regulations provide adequate provisions for enforcement. Some observers have argued that the law went into effect at a convenient time to help China's cause in the struggle in Washington over achieving Most Favored Nation status - and that the law is designed to protect China from US trade sanctions more than Western companies from Chinese counterfeiters.

Peter Gwynne

\section{US Greens go national}

Washington

This week sees the launch of a new political party in the United States. The US Green movement - until now a loose coalition of local organizations - is forming the Green Party-USA, a national body headed by a seven member coordinating committee. The launch of the US party comes as support for the Greens in Europe seems to be waning, now that many of the major European political parties have repackaged their own policies to stress environmental measures. But Charles Betz, a member of the national coordinating committee, is undeterred by these developments. 'If you're a Green, you're in it for the long haul," he says.

Just how a national US Green party will function is still unclear. Betz says that the party will not lobby on Capitol Hill, and that even a narrowly defined set of policy goals is unlikely: the 'grassroots' nature of US environmental activism prevents a central committee from dictating policies to local Green organizations, he says. Instead, the committee will encourage local groups to participate in broadly defined national campaigns, starting with a drive to promote the use of solar-generated electricity. The US Greens' electoral ambitions will for the time being be limited to municipal, and perhaps state elections.

Peter Aldhous

\section{SPACE MISSIONS}

\section{Galileo rescue fails}

\section{Washington}

THE latest attempt to open the jammed main antenna on the National Aeronautics and Space Administration's (NASA) Galileo Jupiter probe has failed. Officials at the Jet Propulsion Laboratory in California had hoped that turning the spacecraft for $\mathbf{5 0}$ hours to shield the antenna from the Sun would release several of the ribs supporting the umbrella-like structure that are apparently stuck against the antenna's central tower (see Nature 352, 655; 22 August 1991). But the cooling did not free the carbon fibre ribs, thought to have become jammed against a series of metal pins on the central tower.

Mission scientists will now turn their thoughts away from the troublesome antenna, to concentrate on Galileo's encounter with the asteroid Gaspra, on 29 October. Data from this flypast will be stored on an on-board tape recorder, and will be transmitted back to Earth later, using the craft's back-up antenna - or the main antenna, if it opens. To return most of the data from Galileo's 1995 rendezvous with Jupiter and its moons, however, a functioning main antenna is essential. NASA plans another cooling manoeuvre in December, when Galileo is farther from the Sun.

Peter Aldhous 